\title{
Community Work and Exile Politics: Kurdish Refugee Associations in London
}

\section{OSTEN WAHLBECK}

Centre for Research in Ethnic Relations, University of Wanwick

\begin{abstract}
Ethnic associations play an important role for refugees in their new country of settlement. However, refugee communities are often politically divided and find it hard to create viable ethnic organizations. This dilemma is highlighted by results obtained from an ethnographic field study of Kurdish refugees in London. The British case is of special interest, since the refugee resettlement policy is characterized by a tendency to emphasize the role of the 'local community'. The article discusses whether the politicization of the Kurdish associations in London has been a help or a hindrance for the creation of refugee assistance organizations. It is argued that, although there is no cohesive Kurdish community, the refugees have been able to establish well-functioning organizations of a more limited nature. In this process the political activism of the Kurdish refugees has been a resource rather than an obstacle.
\end{abstract}

\section{Introduction}

Today the importance of strong ethnic communities is widely acknowledged among migration researchers. Many studies emphasize that associations can have many important functions for ethnic minorities, immigrants and refugees (e.g. Rex et al. 1987; Salinas et al. 1987; Jenkins 1988; Carey-Wood et al. 1995; Joly 1996). In addition to formal associations, informal social networks within the communities are also of significance (Rex and Josephides 1987).

However, it appears that refugees seldom are able to establish strong and united ethnic communities in their new country of settlement. Refugee communities often display a political and social orientation towards the country of origin. In many cases political events and conflicts 'at home' continue to influence, and often divide, the refugee communities. Several sociological and anthropological studies of refugee communities have described political divisions and conflicts within them (Kay 1987; Lundberg 1989; Bousquet 1991; Gold 1992; Steen 1992; McDowell 1996; Valtonen 1997). These studies indicate that the political reasons for flight later contribute to disagreements within communities and often constitute obstacles to the establishment of viable and unitary associations. Yet, there are also indications that the same political convictions which can divide a community, can also

OOxford University Press 1998 
unite those smaller groups of refugees who share the same political beliefs and background in the country of origin (cf. Wahlbeck 1997, forthcoming). Paradoxically enough, it is often the case that refugee communities are greatly divided, usually politically, at the same time as containing large resources for ethnic or political mobilization because of the refugees' similar background and life histories.

This article discusses the extent to which the politicization of refugee associations is a help or hindrance for refugees in their new country of settlement. To be able to combat the various problems they face in the country of settlement, refugees need efficient associations and social networks. Are politically active refugees able to create these? The discussion is based on an ethnographic case study completed in 1995 among Kurdish refugees and their associations in London. The study only included refugees who identified themselves as Kurds, rather than using any other ethnic, national or religious identification. The focus is mainly on the Kurds from Turkey, since these constitute a clear majority of the Kurds in Britain, but Kurdish refugees from Iraq and Iran are also included in the analysis.

The British case is especially interesting since, in refugee resettlement policies, and ethnic minority policies at large, there has been a strong emphasis on 'self-help' within the 'local community'. The article describes the Kurdish associations in London and discusses the functions these had for the Kurdish refugee communities. The article argues that, contrary to what one might expect, the continuing orientation towards the 'homeland' and the consequent strong politicization of the Kurdish associations can be useful resources for the refugees. However, before discussing the Kurdish refugee associations it is useful to describe briefly the history of the Kurdish communities in Britain and outline the specific features of British refugee resettlement policies.

\section{Kurdish Refugees in Britain}

The conflict in Kurdistan is a complex one: international, national and local conflicts overlap in a situation where ethnic identities, economic inequality, political ideologies and religious divisions all play their role (e.g. Bruinessen 1992b; McDowall 1996). The oppression the Kurds face has taken different forms and there are differences in the political situations in the Kurdish parts of Iran, Iraq and Turkey. A common feature, however, is that the conflicts between the governments and the Kurds worsened during the 1980s and early 1990s. There are also serious disagreements and violent conflicts between different Kurdish political parties. At the same time as the situation in Kurdistan has deteriorated, it has become increasingly difficult for refugees to seek refuge within another part of Kurdistan or in the neighbouring countries. Consequently, there is an increased need for asylum outside the Middle East.

Britain has received Kurdish refugees from all parts of Kurdistan. Since the 1970s the UK has been a significant host for Kurdish students, and later 
refugees, from Iraq. The Kurds from Iraq were the first large group of Kurds in the UK, probably because of the historical ties between Iraq and the UK (cf. Al-Rasheed 1994). Since many Kurds from Iraq arrived as university students, today they are often well educated and may have well-established positions in British universities and private companies: Because of the violent conflicts and human rights violations in the area, there has been a continuous flow of Kurdish refugees from Iraq arriving in Britain. The number of asylum applications from Iraq has been higher in the 1990s than in the 1980s.

The Kurds from Iraq have recently been outnumbered by Kurdish refugees from Turkey, who since 1989 have arrived in significant numbers and moved into the Turkish community in north London. The increase in the number of Kurdish asylum seekers from Turkey has been due to the increasingly violent ${ }^{\circ}$ conflict in eastern Turkey, continuous human rights violations and various political, social and economic reasons. A total of 4,650 Turkish citizens applied for asylum in the UK in 1989 (Home Office 1990), of whom a large number arrived in May and June. As a result of this major influx, visa requirements were imposed on 23 June 1989 for all Turkish citizens wanting to enter the UK. The sudden influx of a large number of Kurdish asylum seekers during the spring of 1989 created a dramatic situation in the Kurdish community in north London. The authorities did not have the necessary facilities or the ability to take care of this large group of people. Local authorities, voluntary organizations and churches in north London had to do whatever they could to help the newly arrived Kurdish refugees. The Kurdish associations in London had to shoulder a particularly heavy burden during this period. The areas in London where the asylum seekers arrived, principally the boroughs of Haringey and Hackney, were largely deprived inner-city areas. Among other problems, it was difficult to find proper accommodation for all asylum seekers (cf. Crisp 1989; Collinson 1990; Reilly 1991).

The Turkish community in north London was initially established by Turkish Cypriots who migrated to Britain from the 1950s onwards. The Kurdish refugees from Turkey today constitute a large part of the Kurdish and Turkish community in north London. The Kurds from Turkey seldom speak English upon arrival in the UK and many of them are poorly educated. Thus, many of them face problems in the labour market and are forced to work in different 'sweat shops' in north London. A report from Hackney Council (1993) estimates that there are around 800 clothing manufacturing units in Hackney alone. As the Kurdistan Workers Association (KWA) points out in its Annual Report, many of the employed refugees are 'exploited by the factory "sweat shops" that run in the area, and perform menial, unrewarding work" (KWA 1994: 7). Many of the Kurds who have moved to north London during recent years are from the areas of Marash and Sivas in Turkey and belong to the Alevi religious minority. British policy on asylum applicants from Turkey has changed dramatically in recent years. The number of negative decisions has increased radically in the 1990 s, although the human rights situation in Turkey has not improved. 


\section{Osten Wahlbeck}

Since the revolution in Iran in 1979, Iranian Kurds, together with a large number of other Iranians, have arrived as refugees in Britain. The number of asylum seekers from Iran has declined only slowly since the late 1970s. For several years, the Kurdish parties and other Iranian opposition parties were able to continue their resistance against the Iranian government from the mountains in Kurdistan. However, after the decline of the resistance movement many Kurds have been forced to seek asylum in Europe. It is difficult to estimate the number of Iranian Kurds in the UK. It is possible that many of the Kurds from Iran identify themselves primarily as Iranians and that they cannot therefore be regarded as part of the Kurdish community.

A rough estimation is that there were between 20,000 and 30,000 Kurds living in the UK in the mid-1990s. The number is constantly growing and about two thirds of the Kurds are recently arrived refugees from Turkey. At least 90 per cent of the Kurds in the UK live in London. Despite a common ethnic identity, the Kurds do not constitute a united refugee community in London. One reason is that the Kurds speak different languages and dialects, some of which are mutually unintelligible ${ }^{1}$. Another issue, which is stressed in this article, is the political disagreements and allegiances dividing the community. There is a common Kurdish nationalism which most refugees support, but in practice it can only occasionally unite the Kurds. For example, the celebration of Newroz (the Kurdish New Year) is an occasion which can unite Kurdish refugees from different backgrounds. However, in ordinary day to day life there is not much contact between refugees from different parts of Kurdistan.

\section{Reception and Resettlement Policies in the UK}

In Britain, refugee reception is in practice largely organized by nongovernmental organizations and not by the British authorities. The National Health Service and the Department of Social Security provide their specific services, but more general advice and services are offered by a wide variety of non-governmental service providers. Although funding for refugee reception is to a large extent organized from public sources, the practical work is mainly carried out by various charities and voluntary organizations. In a recent publication, the British refugee resettlement policy is described in the following way:

Central government responsibility for oversight of arrangements for the settlement of refugees rests with the Voluntary Services Unit (VSU), located within the Home Office. VSU's general policy is to provide the help and support needed by refugees through voluntary organizations and community groups, through local authorities, or through special programmes within existing statutory agencies. Compared to national statutory provision, such arrangements are intended to allow greater flexibility and sensitivity to local needs and consumers' voices (Carey-Wood et al. 1995: 1). 
Public funding is available from a variety of sources for organizations working with refugees. The main sources are the Home Office, the local councils and the London Boroughs Grants Unit. There are also other public programmes and private trusts that support organizations working with refugees. Nevertheless, a lack of funding remains a serious problem for many voluntary organizations.

In practice the British authorities have largely handed over the responsibility for the reception of refugees to organizations in the voluntary sector and to the 'local community'. The refugees can thus 'choose' between a number of 'competing' service providers, although in practice different groups come under the care of particular bodies. Clearly, the various organizations form an 'extremely dynamic, determined, and innovative set of actors' (Majka 1991: 273). However, this plurality also means that there are many organizations whose activities overlap and there is often a lack of professionalism among the organizations within the voluntary sector.

The British system of refugee resettlement can be seen as connected to more fundamental perceptions of the roles of the state and civil society, and relations between them. One interesting feature of British society is the emphasis on the 'local community', which is understood to be a part of civil society rather than of the state. The whole immigration and minority policy in Britain is often described as a communitarian policy in contrast to the French citizenship model which emphasizes assimilation (Lloyd 1993, 1994; Melotti 1997). The notion of 'communities' is clearly related to the multi-cultural discourse in Britain. Despite the obvious positive features connected with multi-culturalism, there are several dangers and dilemmas connected with a multi-cultural discourse (cf. Älund and Schierup 1991). According to Anthias and YuvalDavis (1992), there is a multi-culturalist discourse in Britain in which people are seen as belonging to specific, usually culturally defined, communities which are distinct from each other and also have clear boundaries. It can be argued that the British multi-cultural project has not only involved a positive recognition of ethnic minority communities, it has also led to a new culturalist and racist construction of exclusionary boundaries in society. The problem is that the preoccupation with communities has created new divisive lines between people. The 'community' is a label put on a very complex reality. For example, community centres or their leaders are never fully representative or democratically chosen by the people they are seen as representing (Anthias and Yuval-Davis 1992). Different political goals within ethnic groups have also been described by Werbner (1991), who argues that it is the wider society which encapsulates and marginalizes ethnic groups by insisting on community-wide policies. Goulbourne (1991a, 1991b) sees a danger in what he calls the British 'communal option', which has prevented the full inclusion of ethnic minorities into the British national community. This option presumes that there are easily recognizable ethnic or racial categories and that these readily form communities. These exclusionary groups 'are further presumed to constitute the proper boundaries within which individuals should be encouraged to conduct their daily lives' (Goulbourne 1991b: 297). 


\section{Osten Wahlbeck}

At least since the $1980 \mathrm{~s}$, the multi-culturalist discourse has been more dominant than assimilationist policies within social policy in Britain. In social work with ethnic minorities, cultural differences and the importance of consulting with communities became fully acknowledged. Likewise, there was an emphasis on 'self-help' and support to associations working within specific communities (Candappa and Joly 1994).

Refugees are seldom distinguished from other migrants or ethnic minorities in British public discourses. The whole question of refugee admission is connected to the constantly important political issues of immigration and 'race' (Miles and Cleary 1993). Because of the communitarian policies towards ethnic minorities, there is a tendency to regard refugees as 'ethnic minorities' in a multi-cultural society. However, many refugee communities in Britain, including the Kurds, have specific experiences which are very different from those of the British ethnic minorities, whose long history of settlement in the UK often has to be seen within a colonial context. Therefore, there is a danger that the British authorities' policies towards refugees are not always sensitive to refugees' specific social situation and problems.

The fact that social networks and associations are important for refugees seems largely to have been acknowledged in Britain. On the other hand, this acknowledgement seems to assume that associations have to be based on clearly defined homogeneous ethnic communities. The multi-cultural discourse in Britain has included a tendency to impose artificial ethnic boundaries on a diverse and complex social reality. It is even more obvious in the case of refugees than in the case of other ethnic minorities, that there are no clear or simple unitary and homogeneous ethnic communities. The aforementioned political disagreements between refugees seem to be a typical feature of most refugee groups. Thus, multi-cultural policies presuming that there are easily recognizable and cohesive ethnic communities are not always the most suitable for refugees.

\section{Refugee Organizations in London}

\section{British Organizations}

Specific resettlement programmes have been set up for quota refugees in Britain, including Chileans, Vietnamese and Bosnians. Most other refugee groups, including the Kurds, have not been part of any special resettlement programme. However, a wide range of charities and community centres offer refugees support. The first voluntary organization which Kurdish refugees encounter is often the Refugee Arrivals Project (RAP). After arrival at Heathrow most refugees are handed over from the Immigration Service to the RAP, which is funded by the Home Office. It is expected to be able to move people into the community within a day or two of their arrival, an almost impossible task. For example, housing is very scarce in London and the local councils can only provide housing to those with special needs. Single refugees 
must largely fend for themselves and usually face acute housing problems. The RAP writes in its 1993 Annual Report that 'the task we face has become more complex and demanding and the project is stretched to breaking point by the additional pressures on us all' (RAP 1994: 7). Clearly, in this situation many refugees need help and advice from other sources. Perhaps the most important provider of practical help, after refugees have stayed in Britain for a few days, is the Refugee Council. A large organization mainly funded by the Home Office, the Refugee Council has a wide variety of services, programmes and activities giving practical help to refugees and promoting refugees' rights both in Britain and abroad.

In addition to the Refugee Council there are many other smaller and voluntary organizations which give valuable support to refugees. For example, many of my interviewees were grateful for the help they had received from the Medical Foundation for the Care of Victims of Torture. However, in the case of Kurdish refugees, the various Kurdish community centres and organizations in London are of special importance and these are the object of interest in this article. The case study included all associations in London which were working with, or for, Kurdish refugees in 1995 and explicitly identified themselves as Kurdish. This delimitation has excluded Turkish, Iraqi, Iranian and various leftist organizations from the analysis, although many of these have Kurdish members.

\section{Kurdish Associations}

In 1995 there were all in all about 25 Kurdish associations active in London. One problem in counting them was that new organizations were started and old ones disappeared at a bewildering speed. About 10 were community organizations and advice centres which provided advice and services to Kurdish refugees. The community centres often provided a very wide range of services for their members and clients. Their activities included advice on welfare, housing and asylum issues, language and training courses as well as various social and cultural activities. The biggest community centres had bookshops and restaurants on their premises. Usually, newly arrived refugees found the organizations through their friends and relatives, but some of the large and established organizations in London were even known in Kurdistan. It should also be noted that some Kurds chose to organize themselves in associations that were not wholly Kurdish. Kurdish refugees from Iran were mostly active in Iranian political organizations and community centres, while several organizations in north London were visited by both Turks and Kurds.

The oldest Kurdish community centre in London was the Kurdish Cultural Centre (KCC), founded in 1985 and situated in Lambeth. Its members were mainly from Iraqi Kurdistan. Because of the similarity of their dialects, some Kurds from Iran visited the centre as well, especially since there was no organization in London specifically for Iranian Kurds. As one of the largest and oldest Kurdish associations in Britain, the KCC has also tried to be an 
umbrella organization for other local Kurdish organizations in the UK. In recent years the tendency among Kurds from Iran and Iraq has been to establish new local associations (the Greenwich Kurdish Community Association, the Kurdish Community in Ealing, the Kurdish Information Centre in Islington and the West London Kurdish Association in Hammersmith) as well as more specialized organizations (the Kurdish Housing Association, the Kurdish Disability Organization, the Kurdish Scientific and Medical Association and a separate organization for Faili Kurds). This development, together with political disagreements within the Kurdish community, seems to have led to a decline in the activities of the KCC.

The biggest community centres were found in the Turkish and Kurdish communities in north London. The Kurdistan Workers Association in Haringey had between 3,000 and 5,000 Kurdish members and clients from 'North-West Kurdistan' (i.e. Turkey) while the Turkish and Kurdish Community Centre Halkevi in Hackney had about 4,500 members, of whom most were Kurds. Halkevi, established in 1984, was at first called a Turkish community centre and has only emphasized its Kurdishness in the 1990s. Both the Kurdistan Workers Association and Halkevi were very vital organizations with many different activities. During the first half of the 1990s, both centres had elected management committees which were sympathetic to the Kurdish national struggle in 'North-West Kurdistan'. In the early 1990s the support for the Kurdistan Workers Party (Partîya Karkerên Kurdistan, PKK) became more evident among the Kurdish refugees from Turkey. The overwhelming victory of candidates sympathetic to the PKK in elections to the management commitee of the Kurdistan Workers Association in 1990, was preceded by conflicts between different political parties which are described in detail by Reilly (1991). After the election, the activists sympathetic to the Turkish Kurdistan Socialist Party left the community centre. Some later became active in the Kurdish Advice Centre situated in Tottenham.

In addition to the community organizations and advice centres, which provided services and advice to refugees, there were several other Kurdish organizations in London. These were usually oriented more towards the situation in Kurdistan, and were engaged in campaigning, publishing, collecting information, political lobbying and fund-raising for the Kurdish cause. Often both Kurdish and British volunteers could be found in these organizations. During the spring of 1995 the following organizations were wellestablished and active: the Hawkarani Kurdistan, the Kurdish Human Rights Committee, the Kurdistan Human Rights Project, the Kurdistan Information Centre and the Kurdistan Solidarity Committee.

\section{The Politicization of the Kurdish Associations}

What all Kurdish communities had in common was the high politicization of the refugee organizations. This was evident regardless of whether the refugees came from Turkey, Iraq or Iran. With few exceptions, the Kurdish 
organizations in London were associated with certain political groups in the country of origin. The same political allegiances and boundaries that can be found in Kurdistan are thus recreated and modified in exile. Upon arrival in the country of exile, Kurdish refugees clearly preferred to join organizations which shared their political views and avoided organizations which might be associated with conflicting political movements.

Among all Kurdish organizations, support for the 'Kurdish cause' and the struggle of the Kurdish people was clearly expressed through various symbols: political posters, pictures of political leaders and the flags of different political parties. These symbols were found in prominent places in the refugees' homes, in the community centres, at demonstrations and at the Newroz celebrations. A worker in one organization in London explained the political affiliation of Kurdish organizations in the following way:

You know, we are not a football team, or some English organization like that. We are political refugees. There is a specific reason why we came here, and that reason is political and of course one still wants to continue with something that earlier has taken up your whole life.

Political allegiances were most clearly expressed by the organizations of Kurds from Turkey, which often explicitly supported certain Kurdish political parties (see also Reilly 1991). The Kurds from Iraq and Iran often tried to keep their organizations more neutral vis- $\dot{a}$-vis the political parties and their disagreements in Kurdistan. However, this neutrality was difficult to achieve. In London the only associations not connected with Kurdish political parties were small organizations with a very clear and narrow purpose. Although the workers at the Kurdish associations themselves agreed that Kurdish organizations easily became associated with certain political parties, they usually emphasized that the organizations were open for all and that most of their activities had a practical orientation. However, this did not prevent other Kurds from describing organizations according to their political affiliation. There were also obvious problems in the co-ordination of activities among Kurdish refugee organizations affiliated to different political movements.

It should be made clear that the politicization of the Kurdish associations did not mean that the Kurdish community centres in Britain were directly run by political parties. The connection was more complex than this. The community centres had an elected management committee, and even if persons sympathetic to a certain political party were elected to the management committee, this did not imply that the party ran the community centre. In fact, some of the Kurdish parties had their own representatives in London. These representatives were independent of the community centres and were not directly involved in practical work with, or for, refugees in Britain. The politicization of the Kurdish refugee associations can mainly be understood as a process whereby people who are sympathetic to a certain party want to be together with people they feel comfortable with and who agree with them on 
political issues. Of course, the refugee associations themselves want to support the Kurdish cause and play an active role in the liberation of Kurdistan, but in practice it is difficult to fulfil these objectives when the associations are situated in Europe.

It is interesting to note that neither religion nor kinship was used as a mobilizing force in the same way as politics was. Ethnic mobilization is often based on a common religious tradition. Among the Kurds one would thus assume that Islam could be a powerful force around which social networks and associations are built, or that the Kurds would use existing wider Muslim networks and associations as a resource to solve the problems they experience in their new countries of settlement (cf. Joly 1995). However, this has not happened in the Kurdish refugee communities. There was no evidence of Kurdish associations using religion as a mobilizing force. Few of the Kurdish refugees interviewed, although they declared that they were Muslims, had any contacts with mosques or religious organizations. Obviously, the question of the role of religion is a very complex issue and there are several aspects to this which cannot be discussed here. Thus, it is not possible to argue that in general Kurdish refugees are not religious. One issue, among many, which has to be taken into account is that the Kurds from Turkey living in London are mostly Alevis, and therefore do not follow the same religious traditions as Shia or Sunni Muslims. For example, the Alevis do not have any mosques. This might contribute to the Alevi Kurdish community's detachment from Muslim organizations. However, what is surprising is that not even the Alevi faith seemed to be used in the mobilization of the Kurdish community. Taking into account the hostility between Sunnis and Alevis in Turkey (McDowall 1992), one would assume that even in exile this would have an impact on the social organization of the community. In fact, there are some refugees from Turkey who emphasize a separate Alevi identity, rather than a Kurdish or Turkish identity. Yet, the distinction between Alevi and Sunni was not a very relevant one among the Kurdish organizations. My informants in north London repeatedly stressed that the Alevi/Sunni distinction was unimportant for the Kurdish refugee associations. For example, one activist in the Kurdistan Workers Association interrupted me when I tried to ask him about Alevis with the statement: 'This is not important, what is important is that we are all Kurds here'.

Among Kurds the family is a very important social unit in the private sphere of life. Traditionally, the social organization of Kurdistan has largely been based on family allegiances and a 'tribal' structure (Bruinessen 1992a). Not surprisingly, the social networks of individual refugees were largely based on family allegiances. However, despite this, traditional tribal networks did not play a prominent role in the public sphere of life of the refugees. The research showed that there were no Kurdish associations which would be mobilized on the basis of what could be perceived as tribal networks. As Bruinessen (1992a) points out, the tribal structure in Kurdistan has given way over time to allegiances based on nationalist and socialist discourses. The latter political 
allegiances are those which in recent years have also dominated the Kurdish associations in exile.

Consequently, it can be argued that political allegiances and divisions have been more consequential than either religion or kinship. The politicization of the Kurdish refugee associations is a continuation of social networks in Kurdistan. In Kurdistan, the political parties are often important social institutions which also tend to dominate other organizations. Thus, when the political refugees in exile recreate their social networks and establish new associations, it would be surprising if these did not continue to be associated with political parties in Kurdistan. This high politicization of the Kurdish refugee communities replicates the political divisions in Kurdistan and divides the Kurds in exile.

One problem connected with the dominance of the political features of the Kurdish associations is that social groups which are not politically organized, as well as non-political or anti-political individuals, will easily become marginalized in the Kurdish community. This is the case, for example, with Kurdish women, who undoubtedly have a problem in getting their voice heard in the public sphere. In fact, some of the female informants wanted to emphasize that the Kurdish associations are not doing enough to improve the situation of refugee women. Kurdish men who wanted to avoid politics also found that the politicization of the associations was a problem. As one refugee in London told me:

For example [the organization], it is dominated by a couple of political parties. And other organizations also have their own political background. Exile communities have strong rules, strong rules of how you should behave. The organizations give you help, but they also manipulate refugees, or perhaps not manipulate, but at least influence them in a certain way. You have to take part in their way of thinking and in their activities. A lot of people avoid the organizations because of this.

Clearly, the politicization of the associations divides the community since some persons choose to avoid the associations. This leads inadvertently to the associations not being able to provide equal services to all refugees. Thus, the British policy of giving a large responsibility for the resettlement of refugees to ethnic associations within the community cannot be seen as a good way to provide equal services to all refugees. The problem here is not that the associations are mobilized around politics. Rather, the problem is connected to the community-centred policies in Britain, which will always experience problems in providing equal services to all individuals, regardless of the particular basis of mobilization within the communities.

So far, this article has shown that the associations and social networks in exile largely constitute a continuation of social and political allegiances in Kurdistan. The politicization of the associations often divides the Kurdish refugees. Nevertheless, just as politicization divides the Kurds, it can also be a powerful mobilizing force for smaller groups within the wider community. 
Although there is no community-wide association among the Kurds, there are several small and well-functioning associations. Likewise, one cannot talk about one united Kurdish refugee community, but there are still strong social networks among the Kurdish refugees. These smaller social networks and associations constitute important resources for the refugees and can fulfil a number of different functions.

\section{The Practical Functions of Associations and Networks}

Clearly, presenting the opportunity to continue to work politically is one function which the Kurdish organizations and networks can fulfil. Political activism might also serve the function of reinforcing an identity and a sense of order and purpose in the fragmented lives of the refugees. However, the associations also performed a wide range of practical functions. The Kurdish refugees were able to use their associations and their informal networks to overcome many of the practical problems they experienced in their new country of settlement. The difficulties refugees encountered upon arrival and the lack of organized support for refugees in the UK presented the associations with considerable challenges. A man from Turkey who arrived in the spring of 1989 described his arrival in the UK:

The Kurdistan Workers Association helped me. The administration office, where they help Kurds who need help and advice and cannot speak English, I came here straight away ... At the airport, somebody was in charge of Kurdish people, and they brought us here straight away. They gathered the Kurdish people together, perhaps 30 persons, and brought us to the Kurdistan Workers Association.

Many refugees experienced the language barrier as their greatest problem upon arrival in the UK. Most Kurdish associations organized interpretation and translation services in order to help recently arrived refugees. Some of the larger community centres arranged extensive language and training courses. Housing is a major problem for refugees in London. The associations tried to alleviate this problem by providing advice and guidance on housing issues. Since newly arrived refugees are not familiar with British society, there is a great need for all sorts of general advice. The Kurdish community centres in London of ten had specific staff who gave advice to refugees. In addition to paid staff, there were usually many volunteers, both Kurdish and British, working in the different organizations. A large number of Kurds interviewed received most of their initial advice through some of the community centres. Some of the bigger associations were even able to provide legal advice with the help of British solicitors. In addition, all Kurdish associations had different types of cultural and social activities which provided an opportunity for newly arrived refugees to establish important social contacts.

The refugee associations and community centres would be unable to offer the large number of activities and services they do provide without the help of public funding. However, it looks as if the funding available was not always 
sufficient. For example, the associations often had difficulties in obtaining sufficient funds for the language and training courses they organized. The services provided by the associations were thus often hampered by inadequate funding and a piecemeal structure.

Friends and relatives also played a major role in helping newly arrived refugees with their problems in London. In fact, the importance of informal networks in giving practical help often seemed to be greater than that of the associations. A woman from Iran who had received most of her help from friends who had arrived some years earlier told me that:

I do not know if you know, but there is a custom between refugees towards that those who have been here earlier they help newly arrived, and every individual among them works as an association. They were so helpful, they were really so helpful.

Social networks based on social relations in the country of origin are obviously an important source of practical help and advice. In particular, relatives, including distant ones, play an important role for newly arrived Kurdish refugees. Hospitality is in general highly valued among the Kurds (as I myself frequently experienced). Many refugees explained that if another Kurd asked for a favour, it would be unthinkable not to provide help. Nevertheless, one has to remember that resources as well as the ability to give help and advice are limited within the Kurdish community. One very tangible role of the informal social networks is that of giving help to refugees looking for a job. Especially in the large Turkish and Kurdish community in north London, relatives and friends can help each other to find employment and start businesses. A refugee who had repeatedly worked in garment factories in north London explained how to find these jobs:

There is a network, there is a big network. And if you work people come and ask you about your friends, whether you have friends who can work in that place with you ... In factories, you do not have to know English, and most of the refugees they work in factories.

These examples indicate that although the Kurdish community is largely a divided community, there are still well-functioning social networks and associations. The Kurdish refugees tried to use their associations and networks as a resource to solve the different problems they encountered in their new countries of settlement. Even though the Kurdish refugee associations were based mainly on political allegiances in Kurdistan, these associations and networks served totally new additional functions in the country of settlement.

\section{Conclusion}

This study has largely confirmed the findings of other studies which emphasize that refugee communities are characterized by political divisions. However, this article argues that this is not the whole truth. Although a community as a 
whole may be politically divided, there might be viable and well-functioning smaller groups within the community. The Kurdish refugees in London did not constitute a unitary community, largely because political disagreements and allegiances in Kurdistan had a profound influence on the social relations of the refugees. However, at the same time as the Kurds were divided politically, similar forces were also able to unite those refugees who shared the same political beliefs and background in Kurdistan. The refugees used their social networks and politically mobilized associations as a resource when they tried to solve the problems they encountered in their new country of settlement. The Kurdish organizations and networks were able to facilitate the refugees' integration into the receiving society. Although there was no united Kurdish community in London, there were many well-functioning Kurdish associations which fulfilled a variety of important functions for the refugees.

This has implications for the multi-cultural and communitarian policies adopted by the British authorities. Clearly, refugee associations can fulfil many important functions for their members and clients. However, the associations do not necessarily operate on an ethnic, community-wide basis. There are aspects of multi-cultural and communitarian policies which are not suitable for politically divided refugee communities. Although associations are important for immigrants and refugees, there is a danger that the authorities may impose artificial ethnic boundaries on a complex and diverse social reality. For example, in politically divided refugee communities, refugee associations are not able to provide equal services to all persons assumed to belong to the specific ethnic group. Obviously, the whole responsibility for the resettlement of refugees cannot be handed over to communities themselves. There is a need to strike a balance between general welfare structures and functions which can be fulfilled by refugee associations.

1. As a result of the assimilation policy in Turkey, many of the Kurdish refugees from Turkey speak Turkish as their first language and have only limited knowledge of Kurdish. In addition, there are huge differences between the various Kurdish dialects.

AL-RASHEED, M. (1994) 'The Myth of Return: Iraqi Arab and Assyrian Refugees in London', Journal of Refugee Siudies 7(2/3): 199-219.

ALUND, A. and SCHIERUP, C. U. (1991) Paradoxes of Multiculturalism. Aldershot: Avebury.

ANTHIAS, F. and YUVAL-DAVIS, N. (1992) Racialized Boundaries: Race, Nation, Gender, Colour and Class and the Anti-Racist Struggle. London: Routledge.

BOUSQUET, G. (1991) Behind the Bamboo Hedge: The Impact of Homeland Politics in the Parisian Vietnamese Community. Ann Arbor. The University of Michigan Press.

BRUINESSEN, M. VAN (1992a) Agha, Shaikh and Stote: The Social and Political Structures of Kurdistan. London: Zed Books.

- (1992b) 'Kurdish Society, Ethnicity, Nationalism and Refuge Problems', pp. 33-67 in Kreyenbroek, P. G. and Sperl, S. (eds.) The Kurds: A Contemporary Overview. London: Routledge.

CANDAPPA, M. and JOLY, D. (1994) Local Authorities, Ethnic Minorities and 'Pluralist Integration'. Coventry: Centre for Research in Ethnic Relations, University of Warwick.

CAREY-WOOD, J., DUKE, K., KARN, V. and MARSHALL, T. (1995) The Settlement of Refugees in Britain (Home Office Research Study 141). London: HMSO. 
COLLINSON, S. (1990) "The Alevi Kurd Asylum-Seekers: "Refugees" or "Migrants"?" Dissertation for M.Phil. in International Relations, Cambridge University.

CRISP, J. (1989) 'United Kingdom: Fending for Themselves', Refugees 70 (November 1989): p. 18. GOLD, S. (1992) Refugee Communities: A Comparative Field Siudy. Newbury Park, CA: Sage.

GOULBOURNE, H. (1991a) Ethnicity and Nationalism in Post-Imperial Britain. Cambridge: Cambridge University Press.

(1991b) 'The Offence of the West Indian: Political Leadership and the Communal Option', pp. 296-322 in Werbner, P. and Anwar, M. (eds.) Black and Ethnic Leadership in Britain: The Cultural Dimensions of Political Action. London: Routledge.

HACKNEY COUNCIL (1993) Planning for the Turkish/Kurdish Community in Hackney. London: Hackney Council, Environmental Services.

HOME OFFICE (1990) Home Office Statistical Bulletin: Asylum Statistics. London: Home Office, Research and Statistics Department.

JENKINS, S. (ed.) (1988) Ethnic Associations and the Welfare State. New York: Columbia University Press.

JOLY, D. (1995) Britannia's Crescent: Making a Place for Muslims in British Society. Aldershot: Avebury.

(1996) Haven or Hell? Asylum Policies and Refugees in Europe. London: Macmillan.

KAY, D. (1987) Chileans in Exile: Private Struggles, Public Lives. London: Macmillan.

KWA (KURDISTAN WORKERS ASSOCIATION) (1994) Annual Report 1993-4. London: KWA.

LLOYD, C. (1993) 'Research and Policy Issues in a European Perspective', pp. 251-263 in Wrench, J. and Solomos, J. (eds.) Racism and Migration in Western Europe. Oxford: Berg.

(1994) 'National Approaches to Immigration and Minority Policies', pp. 69-77 in Rex, J. and Drury, B. (eds.) Ethnic Mabilization in a Multi-cultural Europe. Aldershot: Avebury.

LUNDBERG, S. (1989) Flyktingskap: Latinamerikansk exil i Sverige och Västeuropa (Refugeeship: Latin American exile in Sweden and Western Europe). Lund: Studentlitteratur.

MAJKA, L. (1991) 'Assessing Refugee Assistance Organizations in the United States and the United Kingdom', Journal of Refugee Studies 4(3): 267-283.

MELOTT1, U. (1997) 'International Migration in Europe: Social Projects and Political Cultures', pp. 73-92 in Modood, T. and Werbner, P. (eds.) The Politics of Multiculturalism in the New Europe. London: Zed Books.

MCDOWALL, D. (1992) The Kurds: A Nation Denied. London: Minority Rights Publications. (1996) A Modem History of the Kurds. London: I.B.Tauris.

MCDOWELL, C. (1996) A Tamil Asylum Diaspora. Oxford: Berghahn.

MILES, R. and CLEARY, P. (1993) 'Migration to Britain: Racism, State Regulation and Employment', pp. 57-75 in Robinson, V. (od.) The International Refugee Crisis. London: Macmillan.

RAP (REFUGEE ARRIVALS PROJECT) (1994) Annual Report 1993. Hounslow: Refugee Arrivals Project.

REILLY, R. (1991) 'Political Identity, Protest and Power amongst Kurdish Refugees in Britain', MA thesis, Cambridge University, Churchill College.

REX, J., JOLY D. and WILPERT, C. (eds.) (1987) Immigrant Associations in Europe. Aldershot: Gower.

REX, J. and JOSEPHIDES, S. (1987) 'Asian and Greek Cypriot Associations and Identity', pp. $11-41$ in Rex, J., Joly, D. and Wilpert, C. (eds.) Immigrant Assaciations in Europe. Aldershot: Gower.

SALINAS, M., PRITCHARD, D. and KIBEDI, A. (1987) Refugee-based Organizations: Their Function and Importance for the Refugee in Britain (Refugee Issues, Working Papers on Refugees, Vol. 3, No 4). Oxford and London: Refugee Studies Programme and British Refuge Council.

STEEN, A. B. (1992) Varieties in the Tamil Refugee Experience in Denmark and England. Copenhagen: University of Copenhagen and Danish Centre for Human Rights.

VALTONEN, K. (1997) The Societal Participation of Refugees and Immigrants. Turku: Institute of Migration.

WAHLBECK, Ő. (1997) 'The Kurdish Diaspora and Refugee Associations in Finland and England', pp. 171-186 in Muus, P. (ed.) Exclusion and Inclusion of Refugees in Contemporary Europe. Utrecht: ERCOMER.

- (forthcoming) Kurdish Diasporas: A Comparative Study of Kurdish Refugee Communities. London: Macmillan. 


\section{Osten Wahlbeck}

WERBNER, P. (1991) 'The Fiction of Unity in Ethnic Politics', pp. 113-145 in Werbner, P. and Anwar, M. (eds.) Black and Ethnic Leadership in Britain. London: Routledge.

MS received August 1997; revised MS received April 1998 